\title{
Jacques Chocheyras, Réalité et imaginaire dans le "Tristan" de Béroul
}

\section{G. Matteo Roccati}

\section{Q OpenEdition}

10 Journals

\section{Édition électronique}

URL : http://journals.openedition.org/studifrancesi/330

DOI : 10.4000/studifrancesi.330

ISSN : 2421-5856

\section{Éditeur}

Rosenberg \& Sellier

\section{Édition imprimée}

Date de publication : 1 avril 2015

Pagination : 122

ISSN : 0039-2944

\section{Référence électronique}

G. Matteo Roccati, « Jacques Chocheyras, Réalité et imaginaire dans le "Tristan" de Béroul », Studi

Francesi [En ligne], 175 (LIX | I) | 2015, mis en ligne le 01 avril 2015, consulté le 18 septembre 2020.

URL : http://journals.openedition.org/studifrancesi/330; DOI : https://doi.org/10.4000/studifrancesi. 330

Ce document a été généré automatiquement le 18 septembre 2020.

\section{(c)}

Studi Francesi è distribuita con Licenza Creative Commons Attribuzione - Non commerciale - Non opere derivate 4.0 Internazionale. 


\title{
Jacques Chocheyras, Réalité et imaginaire dans le "Tristan" de Béroul
}

\author{
G. Matteo Roccati
}




\section{RÉFÉRENCE}

JACQUES CHOCHEYRAS, Réalité et imaginaire dans le "Tristan" de Béroul, Paris, Honoré

Champion, 2011 («Essais sur le Moyen Age», 49), pp. 160.

Le volume rassemble treize articles parus d'abord entre 1992 et 2012; il est organisé en deux parties: «Sur les traces du poète Béroul» et «A la recherche du sens de l'"estoire" selon Béroul». L'«Introduction» (pp. 9-14) brosse une lecture «littéraire» et romanesque $\mathrm{du}$ texte et formule quelques hypothèses «à partir de constatations d'évidence» (p. 10): les deux amants s'astreignent non à la chasteté, mais à la continence, les oreilles du roi Marc sont un avatar des cornes, les trois barons agissent car ils craignent la naissance d'un héritier qui limiterait leur pouvoir, tout le monde est subjugué par Iseut, magicienne irlandaise, Tristan préfigure Hamlet.

2 Voici les titres, avec la date de leur première parution. Première partie: "Boron", "buron" et "borie" de Béroul à nos jours (1998), Trois lieux historiques du "Tristan" de Béroul: le "cellier" d'Orri, la Table Ronde d'“Isneldone", "Saint Lubin" (2004 et 2012), Les lieux dits "La Croix Rouge" au Moyen Âge et leur signification (2005), La "Vie de saint Gilles" et le trafic maritime à l'époque du "Tristan" de Béroul (1992-1995), La voix de "Beros" dans son "Purgatoire de saint Patrice" (2004). Deuxième partie: Souffrance physique, souffrance psychique dans le "Tristan" de Béroul (2002), Le sens du terme "félon" dans la "Chanson de Roland" et le "Tristan" de Béroul (1997), De la tromperie à l'erreur, sémantique du "faux" au Moyen Âge (2002 et 2005), Sur le dernier épisode du "Tristan" de Béroul (2004), Chrétien de Troyes et "Tristan": une nouvelle approche (1996), Le personnage d'Arthur dans le "Tristan" de Béroul (1995), Le regard d'Iseut la Blonde (1995), Du "Tristan" de Thomas au "Tristan" de Béroul. La querelle d'Iseut (2004). L'«Index des noms propres» et l'indication des références des premières parutions terminent l'ouvrage. 